\title{
Norwegian Sociology and the Recognition of the Saami Minority
}

\author{
Hans Petter Sand \\ University of Agder, Kristiansand, Norway \\ Email: hans.p.sand@uia.no
}

Received 15 April 2014; revised 16 May 2014; accepted 23 May 2014

Copyright (C) 2014 by author and Scientific Research Publishing Inc.

This work is licensed under the Creative Commons Attribution International License (CC BY).

http://creativecommons.org/licenses/by/4.0/

c) (7)

\section{Abstract}

At a time when the Saami ethnic minority got little attention by the Norwegian public and the political authorities of the country, sociologists did much to raise public awareness about the conditions of this ethnic minority. In the postwar period of the 1950s and 1960s, sociologists of Norway focused to a large degree on social groups that fell outside the emerging welfare state. Norwegian sociology has been characterized by an approach named "problem-oriented empirism" and also by sociologists playing a vital role as public intellectuals. Sociology professor Vilhelm Aubert (192288) coined the term "problem-oriented empirism" to characterize Norwegian sociology from the end of the Second World War to around 1975. Empirism refers to the importance of sociology being close to social reality. Problem-orientation refers to the importance of choosing research questions that are not only scientifically interesting, but also relevant to society. Vilhelm Aubert was also a leading figure among sociologists playing the role of public intellectuals in this period. Problem-oriented empirism and sociologists as public intellectuals have in particular been the case with regard to Saami research.

\section{Keywords}

Saami Ethnic Minority, Problem-Oriented Empirism, Sociologists as Public Intellectuals, Vilhelm Aubert

\section{The Saami Minority}

The Saami ethnic minority live mainly in large areas of northern Scandinavia and the North-west of Russia. It has been estimated that more than half of the Saami minority, around 40,000 persons, live in Finnmark, the northernmost county of Norway. This county has often been referred to as the core area of the minority. The name stems from their own naming of themselves, Samit. Up to the 1970s the Saami population was often called 
"lapps", "finns” or "mountain finns" by the Norwegians, but these names came to be regarded as discriminatory. Today representatives of the Saami population are active in the worldwide movement for the indigenous peoples.

In Norway a Saami parliament was established in 1989. The parliament deals with matters that earlier on were handled by Norwegian state councils and committees associated with matters of Saami language, culture and social life. The Saami parliament is each year granted a considerable sum of money from the Norwegian state to strengthen and develop culture and way of life. The Saami parliament also has a central position in administering the Finnmark-Law of 2005. This law was enacted by the Norwegian parliament. Through the law the Norwegian government has transferred its ownership of land in Finnmark to an agency called Finnmarkseiendommen ("Finnmark Property"). Finnmark Property is led by a board with three representatives of the Saami parliament and three representatives of the Finnmark county council. From 2006 Finnmark Property administers land and natural resources in the county of Finnmark.

\section{Action Research}

Vilhelm Aubert (1922-1988) was a founding father of modern sociology in Norway. In the beginning of the 1960s (Aubert, 1973a) he conducted together with sociologist Lina Homme a study of a local community in Northern Norway. This local community had in 1962 around 200 inhabitants.

The inhabitants were of the Saami ethnic minority, and they had a reasonable command of spoken Norwegian language, but they had language problems in establishing a degree of written contact with the political authorities. Their incomes were very low, estimated to one third of the average income in Norway. Aubert described their housing standard as miserable, which could be partly responsible for an epidemic of tuberculosis. There were a disproportionate number of invalids and incomplete families. The situation was characterized by a concentration of social problems. The local community had for many years been perceived by the surrounding communities as a place with a disproportionate numbers of social problems.

On this background a sociological survey was conducted aiming at a dissertation in sociology. The researchers did interviews in the households on social, economic and other conditions, as well as participation in daily life in the community. It soon turned out that the situation was desperate compared to the standards of most communities in Norway. There existed misery in the traditional sense of the notion. It also turned out that an intense struggle took place between the local population and the local political authorities about how the problems could be solved. The political authorities were strongly in favor of solving the problems by moving the population to another district, however without any specific plan of locality.

To the researchers this plans seemed like a strong abuse of the population, since the initial studies had shown that this ethnic minority had a very strong integration and a very strong sense of belonging to this particular local community. To Aubert, this obviously represented a value that had made it possible to put up with the misery.

In Aubert's (Aubert, 1973b) opinion it thus became impossible to hide behind some kind research ethics and refrain from doing anything. It turned out to be urgent to the researchers to take on the role of being a channel for viewpoints of the inhabitants towards the administrative and political authorities. At first, the researchers tried to convey certain demands for building a boarding school, a demand that the conflict about moving the population came to focus around. The demands were presented by the researchers to the Norwegian department of Church and Education. The department agreed with the local population. This led to other kinds of actions. The researchers go involved in an extensive social policy counseling, and a social worker was employed for one year at the research project. The participation of the researchers came to range from giving advice about social policy rights the population actually were entitled to and to participation in planning and building small production facilities for fisheries, organizing a course of weaving and some assistance in connection with building houses.

Aubert discussed some effects of this action research project. He argued that it gave insight into how politics and administration works. Because of the practical co-operation with the "clients" , the researchers often went to see administrative offices, and had good reasons for doing so. They came to discuss real problems, not to interview the officials about how they viewed certain questions. Since they came as representatives of a group of clients, this gave them opportunities to reflect on certain problems in the state administration that they otherwise would not have noticed.

He referred to one among many other examples. This is the topic that in relation to the least privileged groups 
in society high expertise and strict professional demands could be an obstacle to solving a problem. During discussions about repair of dwelling houses, it was sometimes argued from the medical profession that some of the dwellings could not at all become dwellings for people seen from a reasonable medical standard. One had to build new houses instead of repairing the old ones. But this ideal demand from the experts had, in several instances, the consequence that in waiting for the best solution, people had to wait for years without any solution at all. Similar problem were faced in planning the fishery warehouse. It could not meet the standards of the fishing experts. But this problem was solved when the relevant instances set the social aspect above the technical and other aspects. This result, however, took a long time to reach.

Little resources were available for this project. This was due to the point of departure. The project was not initiated through political decisions or decisions in the administration. The initiative came from research questions - presumably about poverty — and has to some degree stayed there, although it had contributed to positive efforts also from other public instances.

This research project led to another action research project in Finnmark. But here the researchers worked with two social workers who had particular knowledge of the situation in the community. Thus, the project was immediately focused on practical measures in the form of developing Saami handicraft. Both the Department of Social Affairs and the Department of Church and Education supported the project in various ways and it soon released a strong local initiative.

\section{Saami Identity as Social Stigma}

Harald Eidheim's (Eidheim, 1969) classical article from 1969, describes how a Saami ethnic identity can be a social stigma in areas where no visible traits or way of life distinguishes Saamis from the Norwegian ethnic population. The article in called "When Ethnic Identity is a Social Stigma". He pioneered the study of the Saami minority in Norway writing his first article in 1958. Through the years his writings on the theme became more and more activist in flavor, arguing for the preservation of a Saami ethnic identity, while at the same time granting them equal rights with other Norwegians within the Norwegian state. From the 1970s on, his articles were used by government committees on Saami policies.

In his 1969 article he particularly emphasizes that ethnicity is a relation between groups; that it lies between and not within the groups, and that it is considerable room for personal manipulation and management of ethnic relations.

He uses the terms "lapps" and "lappish", which at that time was a somewhat neutral term also used by the Norwegian government.

In his article, he contrasts the reindeer lapps of the interior of Finnmark with the coastal lapps living in the fjords of Finnmark. The reindeer lapps were more distinct from the Norwegian ethnic population in visible physical traits, mainly speaking lappish on a daily basis, and with own dress constumes. They herded reindeers and migrated with their herds to the green pastures own the coast in the summer.

The coastal lapps, by contrast, looked like most ethnic Norwegians, did farming and fishing and spoke mainly Norwegian on a daily basis. However, when they were on their own, they might speak lappish. However, in encounters with ethnic Norwegians they spoke Norwegian, trying to pass as ethnic Norwegians. But they spoke a slightly broken Norwegian and were thus stigmatized as lapps. In the fjord community that Eidheim studied, Lappish was the domestic language in about 40 of the 50-odd households. In each of the ten households using Norwegian language, at least one person knew Lappish and used it in other social contexts. Lappish must, according to Eidheim, be regarded as a secret language or code, regularly used only in situations where trusted Lappish identities were involved. A most common occurrence in daily life inside the community, was the entry of one of the local Norwegians into a pre-established closed stage. People then immediately switched from Lappish to Norwegian, and themes of conversation were adjusted. The Norwegians not only regarded Lappish as an inferior language, but also judged it highly improper and challenging if it was used in their presence. All Norwegians were monolingual.

This article has been on the basic curriculum for more than 30 years in both social antropology and sociology in Norwegian universities.

\section{The Saami Nation}

The book Den samiske nasjon (Otnes, 1970) (“The Saami Nation”) was published in the beginning of the 1970s. 
Per Otnes was a radical, activist sociologist at that time. When writing the book, he was a research assistant at the same University. After finishing his M.A. in sociology, dealing with organizational problems among Norwegian fishermen, he was encouraged by Vilhelm Aubert to work on the saami organizations.

The work of Otnes resulted in the aforementioned book. The book gave the first comprehensive overview of the political history of the Saami people seen in connection with the economic and historical development of capitalism. The account was to a large extent chronological and followed the basic principles of historical materialism.

Published at a time when the radical student movement gained momentum, the book got a lot of public attention, particularly from the radical Marxist-oriented students.

Otnes used a neo-colonialist frame of reference in his description and analysis. He stuck to the idea that Norway and other Nordic countries, Sweden and Finland, had their own developing countries in the north. Northern Norway, and particularly the county of Finnmark, could be seen as a colony within the Norwegian nation. The Norwegian state had been eager to extract from the abundance of raw materials from this area, leaving the Saami population in poverty and misery. The coast of Finnmark is teeming with fish and there are several ores to be extracted from the mountains of the region. Also, during the cold war, Finnmark had strong strategic significance for Norway and Nato. Finnmark had borders with the Soviet Union. This led to a strong build-up of military bases. These bases contributed to infra-structures and better living-condition for a part of the Norwegian ethnic population in the area.

I will not here go into a description of the various Saami organizations Otnes described. I will only suffice to say that he argued that the organizations could be seen as counter movements to the oppression by the Norwegian state. Also, he pointed to the problems of fragmentation of the interests of the Saami people and the split between the population in Finnmark and a Saami intellectual elite living in the capital of Oslo.

\section{Schooling and Forced Norwegianization}

Professor emeritus of sociology of education, Anton Hoem (1976) published in the mid 1970s a comprehensive study of primary schools in what he termed the Saami core areas. This is the geographical areas in the interior of Finnmark with the most dense reindeer herding Saami population. Hoem compared the results of schooling in these areas with the standards of the Norwegian national plan (1939) for primary schools. He found that in the period from the introduction of the law of primary school of seven years in 1936 to the introduction of a nine years primary school in 1969, the majority of the students in the core areas did not meet the minimum standards of the national curriculum plan.

The students who had the lowest achievements in the schools, were those who went to ambulatory schools. But, at the same time, these students, more than others in boarding schools, were able to acquire more of local knowledge and vocational skills that their parents were carriers of.

Hoem argued that the reason for the low achievements in primary schools in the core Saami regions, had its roots in the relationships between schools and families. While the official view of the problem was one of pedagogical processes, Hoem argued that the problem was due to socialization of the children.

The goal of the Norwegian state for the primary schools in the Saami districts was one of adaptation to the urbanized modern Norwegian society, while to the parents the goal was adaptation to a rural Saami life.

The Norwegian state, took for pedagogical reasons into account that the mother tongue of the Saami students was Saami and not Norwegian. But it did not recognize the Saami ethnic belonging as equal to the Norwegian ethnic belonging. The form of the local community was not seen as equal to the industrialized urban communities. This could have consequences for the functioning of the schools. Formally and informally then, the primary school in these core areas got the function to eliminate the ethnic borders and tensions that might exist, and to further urbanization on the individual level. This task was places on the shoulders of the teachers and the local school leaders. The Saami students and their parents were then subject to a form of pseudo-recognition, according to Hoem. When they were not recognized as equal partners, the teachers and school-leaders came to represent the Norwegian state in relation to the saami students and their parents. This led to schooling in this core saami areas became a closed system. To Hoem, this became a critical situation for the school, since the representation of parents in the schools was fictious and it was a great probability that students and parents experienced the formal recognition as a pseudo-recognition.

\section{Saami Living Conditions}

Aubert's (1978) report from 1978 seems to indicate that problems of living conditions of the Saami population 
in Finnmark had become of some interest to the Norwegian government. Some additional questions on the Saamis had been added to a census of 1970. Professor Vilhelm Aubert was asked to analyze the data, and the results were published in a report called "Den samiske befolkning I Nord-Norge" ("The Saami Population of Northern Norway") issued by Statistisk Sentralbyra of Norway ("Statistics Norway"). The census had registered 10,535 persons with Saami as their mother tongue and 9175 who regarded themselves as Saami. Totally 27,646 persons were registered with a Saami connection, when persons who did not know/were uncertain or did not wish to answer, also were counted as saami. Aubert concluded from this that there were at least 40,000 persons in Norway whose living conditions in some way were affected by their Saami origin.

No matter how the concept of Saami identity was defined, to Aubert it was a typical periphery population, not only on the level of the nation state, but also on the level of local community and local government. The Saamis lived in marginal communities and were concentrated around primary industries like agriculture, fishing and reindeer husbandry. They had a relatively high percentage of retired persons and a relatively low percentage of persons with higher education. Their housing conditions were considerably worse than the ethnic Norwegians. There were relatively more single households among the Saamis than the ethnic Norwegians. The families who had children had relatively more children than ethnic Norwegians.

\section{The Alta Campaign}

Since the late 1960s the Norwegian government had made plans for a large hydro-electric power dam near the village of Alta in Finnmark. The dam would affect Saami areas and pastures for Saami reindeer husbandry. For some time even the Saami settlement of Masi would come under the dam water. But this plan was abandoned. The Saami organizations were against the dam project, and so were Norwegian organizations for environment protection. Also, the municipalities of Alta and Kautokeino in the core saami area voted against the project. But the county council of Finnmark recommended the construction of the dam, and so did the Norwegian parliament. At the same time, the opponents concentrated in the Folkeaksjonen mot utbygging av Alta/Kautokeino-vassdraget ("The Popular Campaign against dam constrctions in the Alta-Kautokeino-watercourse"). In the summer of 1979 the campaign made use of civil disobedience and stopped the construction work for a while.

In October 1979 a group of Saamis camped in front of the Norwegian parliament and demanded a permanent stop of the construction work. Their demands were dismissed by the parliament. The case was brought to court in Alta in 1980. It stated that the construction work was legal. This led to new start of the construction work in January 1981 and a new demonstration of civil disobedience by the Popular Campaign. Rumors held that the police action to remove the demonstrators might become violent. People feared bloodshed. It has later on been revealed that two of the main profiles of the demonstration, professors of criminology and sociology of law, Nils Christie (Kalleberg, 2005) and Thomas Mathiesen (Andenaes, 2005), had secret negotiations with the police authorities to avoid violence and bloodshed. It had been established in the media that many of the demonstrators were willing to die for the cause. Professor Nils Christie commented on this by saying that "None of us had come to Alta to die. We were just here to feel a little unpleasant (It was very cold in Alta at that time). The river was worth that" (Hjorthol, 2006). Several hundred persons had chained themselves to the ground or to each other. More than 600 policemen from all over Norway were sent to remove the demonstrators.

The demonstrators were, however, peacefully removed from the construction site by the police, but on the 24th of January a group of Saamis went on hungerstrike. This strike went on for about a month, until the Norwegian authorities promised to take a new look at the legal side of the construction work. When these questions were clarified in favor of the Norwegian government, the construction work went on without further obstructions.

The Alta campaign was a failure with regard to stopping the construction of the dam. However, in the long run it has had great importance for public awareness of the situation of the Saami minority and consequently the recognition and granting of rights from the Norwegian parliament to this ethnic minority. One could say that the saami minority in this case lost in the short run, but gained in the long run.

\section{Conclusion}

It is fair to say that The Saami Law, the Saami Parliament and The Finnmark Law were direct results of the Alta campaign. Also, the sociologists who wrote on the Saami question since the Second World War contributed significantly to public awareness on the theme. They were all very active public intellectuals. So, while the Alta campaign lost their battle, in the long run the Saami people were victorious and were granted rights by the Nor- 
wegian government.

\section{References}

Andenaes, K. (2005). Thomas Mathiesen. Norsk Biografisk Leksikon (“Norwegian Encyclopedia of Biographies”) Oslo.

Aubert, V. (1973a). Aksjonsforskning. Sosialpolitikken og Samfunnsforskningen ("Action Research” in "Social Policy and Social Research”). Oslo: Ministry of Social Affairs.

Aubert, V. (1973b). Aksjonsforskning og sosialpolitikk (“Action Research and Social Policy”). In Axelsen, T., \& Finseth, A. (Eds.), Aksjonsforskning i teori og praksis ("Action Research in Theory and Practice”). Oslo.

Aubert, V. (1978). Den samiske befolkning i Nord-Norge ("The Saami Population in Northern Norway” Statistisk Sentralbyrå ("Statistics Norway"). Oslo.

Eidheim, H. (1996) When Ethnic Identity Is a Social Stigma. In Hylland Eriksen, T. (Ed.), Sosialantropologiske grunntekster ("Basic Text in Social Anthropology”). Oslo.

Hjorthol, L.M. (2006). Alta. Kraftkampen som utfordret statens makt (“Alta. The Struggle over Hydroelectric Power That Challenged the State Power”).

Hoem, A. (1976). Makt og kunnskap ("Power and Knowledge”).

Kalleberg, R. (2005). Nils Christie. Norsk Biografisk leksikon (“Norwegian Encyclopedia of Biographies”).

Otnes, P. (1970). Den samiske nasjon (“The Saami Nation”). Oslo. 